\title{
世界の多職種連携教育（IPE）と関連する国際的な活動
}

\author{
荒川直子†
}

\section{Global Practices of Interprofessional Education (IPE) and Relevant International Activities}

\author{
Naoko Arakawa ${ }^{\dagger}$ \\ FIP Collaborating Centre, UCL School of Pharmacy; 29-39 Brunswick Square, London, WC1N 1AX, U.K.
}

(Received January 9, 2017)

\begin{abstract}
Activities related to interprofessional education (IPE) vary between countries according to local and national health needs and systems. The International Pharmaceutical Federation (FIP) Education Initiative endeavors to provide a global vision in IPE by the sharing of experiences and gathering of evidence collaboratively to facilitate countrylevel initiatives. The purpose of this paper is to contribute to the further development of IPE activities in pharmacy in Japan through sharing global perspectives and activities related to IPE. FIP Education Initiative published the Interprofessional Education in a Pharmacy Context: Global Report in September 2015, which marked a milestone in the growing recognition of IPE in pharmacy globally. The paper shared global and regional perspectives and experiences in IPE in pharmacy, both from the report and FIP activities. This paper can be seen as a snapshot of IPE-related international activities, which enables gaps and challenges in implementing IPE activities in Japan to be identified. This paper provides an opportunity to explore global trends and initiatives regarding IPE, and to consider how to form and implement IPE specifically based on Japanese health needs and systems.
\end{abstract}

Key words_—interprofessional education; global initiative; collaborative practice

\section{1. 背景}

医療従事者間での連携と協働がより質の高い医療 提供において重要であることは，世界保健機関 （WHO）を含む多くの国際機関や各国の医療関係 機関にて支持されている. ${ }^{1)}$ 患者が抱える疾患とそ の治療や使用される医薬品は益々複雑化してきてお り, 安全で効果的な医療を提供する上で医薬品の工 キスパートである薬剤師は医療従事者間協働チーム に欠かせない. ${ }^{2)} \mathrm{WHO}$ では協働チームで働くこと のできる医療従事者を育てるためには，多職種連携 教育（interprofessional education; IPE）が鍵とな ると言及している。 ${ }^{3)}$

IPE に関連する活動は，地域と国の保健ニーズと システムにより国々で多様だ. ${ }^{2}$ 国際薬剤師・薬学

UCL 薬学部 FIP 協㗢センター(29-39 Brunswick Square, London, WC1N 1AX, U.K.)

現所属： ${ }^{\dagger}$ Royal Pharmaceutical Society (66-68 East Smithfield, London, E1W 1AW, U.K.)

e-mail: naoko.arakawa.11@ucl.ac.uk

本総説は, 日本薬学会第 136 年会シンポジウム S03 で 発表した内容を中心に記述したものである.
連合 (International Pharmaceutical Federation; FIP) と FIP 教育イニシアチブ（FIP Education Initiative; FIPEd) は，協力して国レベルのイニシアチブを促 進するため, 経験の共有とエビデンスの収集により IPE に関する国際的なビジョンの提供に尽力してい る.

筆者は 2012 年からの 4 年間, 英国はロンドンに あるユニバーシティー・カレッジ・ロンドン大学薬 学部にて FIP との共同研究を行ってきた。 その海 外での薬学教育に関する研究活動を踏まえて, IPE とそれに関連する国際的な活動について日本薬学会 第 136 年会のシンポジウムで発表する機会を得た. このレビューでは，その発表内容を記すことによっ て国際的な IPE 関連活動を共有し，日本の薬学に おける IPE 活動の更なる発展へ寄与することを目 的とする.

\section{2. 多職種連携教育（IPE）とその国際的な位置} づけ

IPE にまつわる専門用語に関して，誤つて理解さ れていることが世界中で見受けられる。この誤解と 混乱はしばしば適切な IPE の導入とその評価に影 
響を及ぼしている．WHO によると，IPE は 2つ， 又はそれ以上の医療そしてソーシャルケア職種のメ ンバーが，効果的なコラボレーションを可能とし， 患者への医療効果の向上という共通の目標に向か い，お互いについて，お互いから，そしてお互いが 一緒に，相互影響しながら学ぶときに得られるもの としている. ${ }^{4)}$

この WHO の定義を受け, FIPEd IPE レポート1) では，IPE は上記目標に向かい意図的に行われる教 育手段であり，度々誤解されている多職種間，又は 学際的な教育との違いを明らかにしている。この中 でも度々間違って同意義として使用されるのは他職 種間教育（multiprofessional education; MPE）で ある.MPE とは，多職種の学生が同時に学習する ことを指した，多職種間での並行する教育のことを 言い，職種間で相互に影響し合うことは少ない. ${ }^{1)}$ 例えば，大きい講堂で多職種の学生達が同じ講義を 聞くことが挙げられる。この 2 つの専門用語の意義 の違いは, 現在の医療提供のあり方にも通じるとこ ろがあるため, 明確に理解する必要がある.

現在の医療の多くは多職種による並列したサービ 又提供を行っている。これは多職種医療（Multiprofessional practice）であり，専門分野間の相互 作用が少ない。 それに対し，WHO が目指すこれか らの医療提供のあり方は多職連携医療（Interprofessional collaborative practice) であり, 多職種 医療従事者達が患者，家族，介護者とともに最善の 医療を提供するために働くことを示す。3)これには 各専門職が相互に各自の能力を使用し，グループと して医療提供を行うことが必要だ。こういつた連携 医療による包括的な医療効果の多くがエビデンスと して示されており，多職種連携医療は医療効果の向 上だけでなく，世界的な医療従事者不足を補う点で も注目されている. ${ }^{3)}$

医薬品が予防や治療計画の一部であるのであれ ば，安全で適切な医薬品使用を確実にする上で，薬 剤師は最良の医療を提供する際に欠かせない. ${ }^{1)}$ 薬 剂師の持つ医薬品とその使用に関する専門知識と能 力は多職種連携医療チームと患者への医療効果に多 くの利益をもたらす. ${ }^{2}$ 薬剂師の多職種連携医療 チームへの貢献の度合いはその薬剤師の能力, 医療 ニーズ，医療システム等多くの要因による，その薬 剤師が連携医療の即戦力となるチームワークスキル
や臨床能力を形成するのに鍵となるとされているの が IPEである. ${ }^{1,3)}$

\section{IPE と Collaborative Practice の関係}

WHO と FIP は，IPE が連携医療の即戦力とな る医療従事者を輩出する基礎となり，その医療従事 者による連携医療は医療システムを増強し，患者へ の医療効果の向上へつながるとしている. 2,3$)$ いまだ 医療従事者間の連携は問題も多く，連携医療と効果 的な医療には，まずは効果的な IPE の設立が不可 欠であり，それは最善の医療を患者へ提供するとい う共通の目的を共有しなければならない. 1,5) これを 踏まえ，2013 年にWHO により発表された医療従 事者教育とトレーニングに関するガイドラインでは, IPE は 11 個ある勧告のうちの 1 つとして挙げられ ている. ${ }^{6)}$

FIP 年次世界会議では, 実際に IPE の構築や連 携医療に携わる教育者や薬剤師から「学生が学部教 育の中で多職種連携医療チームとして教育されてい れば，現場に出ても自然に連携医療チームとして働 く」という実例が共有されている，既にでき上がつ ている従来の教育方法は, 欧米では家畜飼料や穀物 などの貯蔵庫にたとえ，各医療専門職分野が $1 つ 1$ つの塔として同列で孤立していることを表してい る。この状態では前述の多職種医療にはなるもの の，ここから多職種間連携医療を作り上げるのは大 変な時間と労力が必要であると言われている，その ため, 効果的な IPE の導入が推奨されている.

IPE 導入と連携医療の実際の乘離による問題もあ る. 2015 年 FIP 世界会議で共有された事例では, 実際の医療では個々の専門職が並列した多職種医療 を提供している状態で，IPEを新しく導入した学部 教育を卒業した薬剤師が直面する問題が示された. 実際の医療現場では連携医療を行う体制が整つてお らず，IPE を経験している薬剤師は連携医療の必要

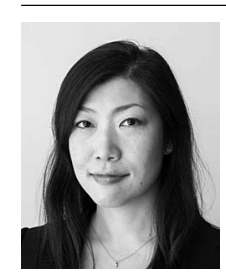

荒川直子
2002 年明治薬科大学衛生薬学科卒業 後, 病院薬剂師, 地域薬局薬剂師とし て従事後, 渡英しユニバーシティー・ カレッジ・ロンドン大学薬学部の臨床 薬学修士課程を 2011 年に首席卒業. 2012 年より同大学薬学部博士課程へ進 学し, FIP, WHO, IPSF と協働で薬 学教育の質を多方面から国際的に調 查. 現在は英国王立薬剤師協会にて日 本薬剤師会との協働事業へ従事. 
性を理解しているものの課題が多く障壁に阻まれ, 混乱してしまう。薬学教育は医療・保健ニーズを基 に構築されるべきであり，未来の理想とする医療シ ステムを想定して構成する必要がある。このため, IPE の導入は必要不可欠であり将来の連携医療の即 戦力となる薬剤師の輩出は重要な問題だ.

ここで挙げられた IPE と実際の医療の乘離によ る混乱は，薬学教育全体を通して身につけるべき コンピテンシーによって埋めることができる.

$\mathrm{WHO}^{7)}$ は，薬剤師を含むすべての医療従事者が かならず獲得しなければならないコンピテンシーを 4 つ挙げている.（1）チームで働く能力，(2) 変化に 適応する能力，(3) 必要時に新しいことを導入する 能力，そして，(4）自主的に, 又生涯を通じて学習 し続ける能力である. IPE で培つた連携医療チーム として働く能力とともに, 必要時に新しいことを導 入する能力を保持することができれば，連携医療の 導入のためにどうすればよいのかを考え，結果的に 導入へ導くことになるだろう。

IPE の導入やその内容は国や地域によって様々で あるが，いわゆる先進国と後進国ではその違いは著 しい. Meads と Barr ${ }^{8)}$ は先進国は個人やその家族 に合わせた医療への準備へ焦点を当てているが，後 進国では IPE の意義を地域発展と公共事業の資源 を合理化する連携医療へ適応していると指摘してい る。その中で，こういった国々の間のより多くの議 論や経験の共有を学ぶことは，IPE を導入する上で より効果的な推移を望めるとしている。これは, FIP と FIPEd がよりよい IPE の構築のために尽力 していることである. そのために行われている IPE に関する FIP を通した国際活動を薬学教育に注目 して紹介する.

\section{IPE に関する国際的な活動}

FIP は現在 96 力国から 137 の加盟団体を抱え, 約 300 万人の薬剤師・薬科学者を代表する国際連盟 で，WHO と公式連携を結ぶ団体である. ${ }^{9)}$ その中 で, FIPEd という, 学部教育から生涯学習までの すべての薬学教育とトレーニングに関する活動を行 う部門が存在する。ここには中心となる教育開発 チームがあり, 現在 IPE を含む 10 個の分野を持つ.

IPE チームは，国レベルのイニシアチブを協働促 進するため, 経験の共有とエビデンスの収集を主 導・実行し，IPEに関する国際的なビジョンの提供
に尽力している，その活動には 2015 年 9 月に発表 された「IPE in a Pharmacy Context: Global Report」 ${ }^{1)}$ の作成も含まれる.

この FIPEd IPE レポートは，IPE に関連する国 際的な活動をスナップショットとしてまとめ, 混同 しがちである専門用語を定義した。さらに，各国の 取り組みをケーススタディーとして提供することに よって，IPE と連携医療の重要な関係を強調してい る.その上で，現在の研究のギャップを特定し，今 後の IPE について議論の切掛けを提供している.

また, IPE チームは, FIP 年次世界会議で IPE に関連するセッションや，特に IPE に係わる教育 者や研究者, また興味がある人々での小規模な フォーラムを行っている。 このIPE フォーラムで は, 関連する進行中の問題や課題を話し合い, 今後 の IPE に必要なエビデンスや IPE チームの方向性 を話し合っている.

こういった活動の中で，共通の問題として挙げら れるのは，IPE のインパクトに関するエビデンスが 不足しているということであり，コクランレビュー でも指摘されている. ${ }^{5)}$ IPE による学生の意識や能 力の向上については発表されているものの, 特に医 療提供過程や，患者への医療効果に対する IPE の 影響についてのエビデンスが圧倒的に不足してお り, 1)また発表されていてもその評価方法の質は乏

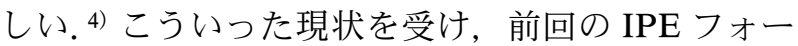
ラムでは, 薬学教育内での IPE 関連研究の質向上 を目的として，「Measuring the Impact of Interprofessional Education on Collaborative Practice and Patient Outcomes」10) というレポートの出版を発表 した。このような IPE とその研究内容の向上のた めにも経験や知識の共有は必要不可欠である.

IPE チームの今後の動向としては, FIP 年次世界 会議での継続した IPE 関連セッションとフォーラ ムの開催のほか, 連携医療の向上を手助けするため の FIP の戦略の構築や，連携医療を目指す教育と トレーニングに関するレポートや論文等の出版を推 奨していく。こういった IPE に関する国際的な活 動へより多くの日本の IPE 関連教育者と研究者や 連携医療に携わる薬剤師が参加することによって, 今後の日本の IPE 評価や研究の向上にも役立つで あろう。 


\section{5. まとめ}

最後に, FIPEd IPE レポートより「IPE は，よ りよい医療という目的地を目指した旅程である」と いう一文を紹介する．IPE を行うことを目的とする のではなく, 患者や社会全体へのよりよい医療の提 供を目的とし，学部教育初期から，継続的な専門能 力開発，そして生涯学習まで続く道のりであるとい う概念を基に，日本のIPE と連携医療の発展を目 指していくことを祈念する.

FIP と FIPEd は，今後も国際的な動向とイ二チ アチブを探求し, 各国の薬学教育の発展を支援し続 けることを約束している，そのためには，世界中か らの教育の経験の共有が不可欠であり，日本の薬学 教育の経験を共有，また世界の経験から学ぶために より多くの薬学教育関係者の従事が望まれる.

謝辞本稿を執筆するにあたり，共同研究を通 して国際的な活動を支援して頂いた FIP と UCL School of Pharmacy に感謝申し上げます.

利益相反＼cjkstart開示すべき利益相反はない.

\section{REFERENCES}

1) International Pharmaceutical Federation. "Interprofessional Education in a Pharmacy Context: Global Report 2015," 2015: 〈http:// fip.org / files / fip / PharmacyEducation / IPE report/FIPEd_IPE_report_2015_web_v3. pdf $\rangle$, cited 30 September, 2015.

2) International Pharmaceutical Federation. "FIP Reference Paper Collaborative Practice," 2009: 〈https://www.fip.org/www / uploads $/$ database_file.php?id $=319 \&$ table_id $=\rangle$, cited 20 March, 2016 .

3) World Health Organization. "Framework for
Action on Interprofessional Education \& Collaborative Practice," 2010: 〈http://www. who.int/hrh / resources / framework_action / en/>, cited 20 March, 2016.

4) Reeves S., Boet S., Zierler B., Kitto S., J. Interprof. Care, 29, 305-312 (2015).

5) Reeves S., Perrier L., Goldman J., Freeth D., Zwarenstein M., Cochrane Database Syst. Rev., (3), CD002213 (2013).

6) World Health Organization. "Transforming and Scaling Up Health Professionals' Education and Training," 2013: 〈http://www.who. int/hrh/resources/transf_scaling_hpet/en/>, cited 20 March, 2016.

7) World Health Organization. "Transformative Scale Up of Health Professional EducationAn Effort to Increase the Numbers of Health Professionals and to Strengthen Their Impact on Population Health," 2011: 〈http://www. who.int / hrh / resources / transformative_education/en/ $>$, cited 30 May, 2013.

8) Meads G., Barr H., "The Case for Interprofessional Collaboration: In Health and Social Care," Chap. 8, ed. by Meads G., Ashcroft J., Blackwell Publishing Ltd., Oxford, 2005, pp. 135-149.

9) International Pharmaceutical Federation. "International Pharmaceutical Federation Annual Report 2015: Empowerment through sharing," 2016: 〈http: // fip.org / files / fip / publications/2016-05_FIP_Annual_Report_ 2015.pdf $\rangle$, cited 20 March, 2016.

10) Institute of Medicine. "Measuring the Impact of Interprofessional Education on Collaborative Practice and Patient Outcomes," The National Academies Press, Washington, DC, 2015. 